Received: 13 March 2017

Accepted: 28 April 2017

Additional information is available at the end of the article.

KEYWORDS: King Richard III; mitochondrial DNA; haplogroup; J1c2c3; mutation; A12397G

\section{King Richard III and his mitochondrial DNA haplogroup J1c2c3}

Ian S. Logan and David N. Brinkman

\begin{abstract}
King Richard III has been a controversial figure for centuries and the finding of his skeletal remains under a car park in 2012 has only raised his profile. But what is generally unknown is that he belongs to an exceedingly uncommon mitochondrial haplogroup, $\mathbf{J 1} \mathbf{1} \mathbf{2} \mathbf{3}$. Two maternal descendants of his extended family have already been traced by orthodox genealogical methods, but no other possible descendants have been found in Europe. In our study we have identified a total of seven lineages containing people in haplogroup J1C2c3 through the use of direct-to-customer DNA testing. All the lineages are American, and unfortunately they do not link back to King Richard III, as yet. However, we do suggest that because of the small size of haplogroup J1c2c3 the people we have identified may well be descendants of the immediate family of King Richard III.
\end{abstract}

\title{
Introduction
}

Richard III was king of England from 1483 to 1485 . But despite being on the throne for only a very short time, he is one of the most famous of all the kings of England. He is remembered largely because of several events that happened in his short life. The first is the strange way in which he came to be king. The second concerns his involvement with the disappearance of his two young nephews, the Princes in the Tower. The third, the dramatic circumstances of the Battle of Bosworth Field on the 22 August 1485 when Richard III was killed, and Henry Tudor became King Henry VII. But more recently he has been in the news again, since his skeletal remains were discovered underneath a car park in Leicester in 2012.

\section{The case against Richard III}

William Shakespeare's famous play, The Tragedy of King Richard The Third, ${ }^{1}$ written just over one hundred years after Richard's death, makes Richard out to be a villain. In fact, he is perhaps the most infamous of all the characters in Shakespeare's many plays. The play was written for a Tudor audience and would have been seen by Queen Elizabeth I, a descendant of Henry VII, so it is perhaps not a surprise that Richard III is the villain and Henry VII the saviour of the country.

Richard's crimes, according to Shakespeare, are numerous and started while his oldest brother, King Edward IV, was still alive. Richard, so it is claimed, hired assassins to murder his older brother, George, Duke of Clarence, thereby removing the main obstacle to stop him from ever being king. Then, on Edward IV's death Richard seized the throne and imprisoned the two young sons of Edward IV in the Tower of London; and had them murdered, too. In the play, Richard is said to murder again and again; but in the end England is saved by the rightful heir to the throne, Henry Tudor, as Richard is killed whilst fighting in the Battle of Bosworth Field.

\section{The case for Richard III}

However, Shakespeare is a story teller and much of what he describes is incorrect. Recent studies have done a lot to show that Richard III should not be described as a villain ${ }^{2}$ but, even so, not everyone disagrees with Shakespeare. ${ }^{3}$

The historical record would appear to contain good evidence showing the young Richard to be a loyal and trusted assistant to his older brother King Edward IV; and as an example of this, Richard was considered as the representative of the king in the north of England for several years. Their brother George, Duke of Clarence, was actively disloyal and this led to his execution for treason in 1478. Moreover, there is no indication that Richard was in any way involved in Clarence's death. On Edward IV's death, it was Richard who was designated to be the 'Protector' of Edward IV's son Edward, aged twelve, who was expected to be crowned Edward V. This means it is not surprising that Richard 
escorted the boy to London, and lodged him in the royal apartments of the Tower of London. A little later, Edward's brother, Richard of Shrewsbury, aged nine, joined him.

However, the next event appeared to have been unexpected by everyone, as Parliament declared the marriage of the late King Edward IV to be bigamous, and his sons to be illegitimate. Again, there does not appear to have been any interference from Richard in this decision, but it did result in Richard being considered as the rightful heir to his older brother, Edward IV; and within a few days he was crowned King Richard III, to popular acclaim. The fate of the two young princes has never been determined. There is no evidence to prove that Richard was involved in their murder, and the boys may have died from natural causes. The real mystery is that the fate of the boys is just not known.

\section{The Battle of Bosworth Field}

Shakespeare describes this battle as between the opposing forces of the evil Richard III and the good Henry Tudor. But in reality Richard III was a popular king and had been able to assemble quite a large army, albeit very hurriedly. Moreover, he had fought in several important battles since the age of eighteen and was a skilled commander. In contrast, Henry Tudor was an invader leading an army of experienced foreign mercenaries. Henry did have a tenuous claim to the English throne, but clearly he was unsure that he could ever defeat Richard in a pitched battle, although he chose to take the risk. The armies met on Bosworth Field on 22 August 1485 . Henry had a small army, but the soldiers were battle-hardened and fairly well equipped. On the other side, Richard had perhaps 10,000 men, but they had been brought together over just a few days and their equipment was generally poor. It would appear that just after the battle started, Richard thought a direct assault against Henry would lead to a quick victory. But Henry's mercenaries proved too strong and Richard was trapped and killed.

\section{The discovery of Richard III's remains and subsequent interment}

In September 2012, in a blaze of publicity, a team of researchers from the University of Leicester started an archaeological exploration to find the remains of King Richard III. The project had been strongly supported by members of the Richard III Society and in particular by the work of historian John Ashdown-Hill who had identified a living maternal descendant of Richard's extended family. ${ }^{4}$ The grave was thought to lie under a car park and it was uncovered on the first morning. Subsequently, the remains were examined in great detail and the research team was able to announce that the remains were indeed those of King Richard III., ${ }^{5,6}$ One of the several strands of the evidence used to confirm their claims was the fact that the mitochondrial DNA (mtDNA) isolated from the skeleton matched that of the two people identified by genealogical studies as being maternal descendants of the sister of Richard III.

The remains of King Richard III were later buried in Leicester Cathedral and his new monument is proving to be a very popular tourist site.

\section{Mitochondria and mitochondrial DNA}

In our bodies most cells have a nucleus containing chromosomal DNA in the form of twenty-two pairs of autosomal chromosomes and a single pair of sex chromosomes, either XX in a female, or XY in a male. But most of our cells also contain mitochondria, small bacteria-like organelles, and these have small amounts of another form of inheritable DNA - the mtDNA. Whereas there is usually just one nucleus in a cell, there can be many hundreds, or even thousands, of mitochondria in a cell, depending on the cell type. For example, liver cells often have over 2000 mitochondria in each cell. The molecules of the mtDNA do have the form of the famous double helix, but whereas chromosomal DNA is in long strands, mtDNA is circular and made up of about 16,569 nucleotide bases. The bases are Adenine, Cytosine, Guanine or Thymidine (shortened to A, C, G and T). Each mitochondrion contains a variable number of mtDNA molecules, resulting in the majority of our cells having over five hundred copies of the mtDNA in each cell. Usually every one of the mtDNA molecules in a person's cells has the identical base sequence (and the person would be described as being homoplasmic), but it is possible to have a proportion of mtDNA molecules having differing bases (and such a person would be described as showing heteroplasmy). mtDNA is maternally inherited, that is to say it is passed down from a mother to her children, but thereafter only a daughter can pass it down to the next generation. This pattern of inheritance occurs because a fertilised egg does not contain any mtDNA derived from the male sperm and all the mtDNA in the developing embryo will therefore be that of the mother. ${ }^{7,8}$

\section{Nucleotide base sequencing of the mtDNA}

The sequencing of the human mtDNA molecule was first achieved in 1982 in Cambridge, UK $^{9}$ and this first complete sequence has since been used as the Cambridge Reference Sequence (CRS). The sequence was revised slightly in $1999 .{ }^{10}$ In this article the numbering of the bases in the mtDNA, from 1 to 16,569 as described in the revised sequence (the rCRS), is used throughout. ${ }^{11}$ (But the common usage nowadays is to use the simple abbreviation CRS, in place of the more correct $\mathrm{rCRS}$.)

Initially, sequencing of the mtDNA was very laborious and expensive as this involved determining the identity of each base one at a time. But now Next-Generation-Sequencing (NGS) ${ }^{12}$ is often used and allows direct-to-customer companies to offer complete mtDNA sequencing to the general public at a low cost. 
A second system of determining the bases present in the mtDNA has emerged in recent years as a useful but incomplete method and involves the determination of a single base by Single Nuclear Polymorphism (SNP) testing. ${ }^{13}$ This type of testing is used by the company 23 andMe and they use a chip-based system to test about 2000 bases of the mtDNA. The system has many limitations, but it can provide useful data and has the advantage of having a very low cost. A newer company, LivingDNA (part of the DNA Worldwide Group), says that it is using a chip-based system covering over 4000 bases of the mtDNA, but no results have appeared as yet.

\section{mtDNA haplogrouping}

The nucleotide bases in the mtDNA do mutate over time and this allows for a phylogenetic tree to be constructed. Most mutations are described as being transitions and these are when an $A$ changes to a $\mathrm{T}$, or a $\mathrm{C}$ to a $\mathrm{G}$, or vice versa in each case. Less common are transversions where $\mathrm{A}$ or $\mathrm{T}$ changes to $\mathrm{a} \mathrm{C}$ or $\mathrm{a} \mathrm{G}$, and $\mathrm{C}$ or $\mathrm{G}$ changes to $\mathrm{A}$ or $\mathrm{T}$. Mutations can also be deletions or insertions when one or more bases are absent, or extra, as compared to the CRS.

In 1987 it was shown ${ }^{14}$ that the mitochondrial gene pool originated in Africa, about 200,000 years ago, and only much later spread to the rest of the world. The first report describing an early mtDNA phylogenetic tree appeared in 1993 when a survey of Native Americans showed that they could be separated into four groups. These groups were termed haplogroups A, B, C and $\mathbf{D}$. ${ }^{15}$ Further haplogroups appeared rapidly and by the following year the European haplogroup $\mathbf{J}$ had been defined. ${ }^{16}$ The mutations that specifically define haplogroup $\mathbf{J}$ are nowadays described as C295T, T489C, A10398G, A12612G, G13708A and C16069T; where, for example, the nucleotide at base 295 has mutated from C to $\mathrm{T}$, as compared to the CRS.

As the phylogenetic tree was being developed, it became possible to put forward theories about the spread of mankind. Important papers were published in 1996 by Richards et al. ${ }^{17}$ and in 1998 by Torroni et al. ${ }^{18}$ that detailed the spread of mtDNA haplogroups over the whole of Europe. In 2001, Professor Bryan Sykes published his book The Seven Daughters of Eve ${ }^{19}$ which was written for a general audience and used information from the phylogenetic tree to describe the peopling of Europe by seven distinct mitochondrial haplogroups, $\mathbf{H}($ Helena), $\mathbf{V}(\mathrm{Velda})$, J (Jasmine), $\mathbf{T}$ (Tara), K (Katrine), $\mathbf{U}$ (Ursula) and $\mathbf{X}$ (Xenia). The book did a lot to stimulate direct-to-customer DNA testing. Sykes suggested that his Clan Jasmine was the grouping for about $17 \%$ of native Europeans. However, a recent paper by Pala et al. in $2012^{20}$ suggests slightly lower figures, with haplogroup $\mathbf{J}$ making up almost $9 \%$ of Europeans and maybe $13 \%$ of people in the Near East.

Over the past sixteen years, our knowledge of the structure of haplogroup $\mathbf{J}$ has expanded greatly and the latest version (mtDNA tree Build $17)^{21}$ of the mtDNA phylogenetic tree describes haplogroup $\mathbf{J}$ as having 234 subgroups - each defined by a distinctive set of mutations. The mtDNA of King Richard III is described with the label $\mathbf{J 1} \mathbf{1} \mathbf{2} \mathbf{c 3}$, which means he is in haplogroup $\mathbf{J}$, and in turn, in haplogroup $\mathbf{J 1}$ defined by the additional mutations C462T and G3010A, haplogroup J1c by G185A, G228A and T14798C, haplogroup J1c2 by A188G, haplogroup J1c2c by T146C, G10685A, T13281C, A13933G, and finally to haplogroup J1c2c3 which has the additional distinctive mutation A12397G. Note that at each stage a smaller number of people are in a particular haplogroup; so if the population size of haplogroup $\mathbf{J}$ and all its subgroups is taken to be around $9 \%$ of Europeans, a pro rata method would suggest that there are about three million persons in haplogroup $\mathbf{J 1} \mathbf{c 2} \mathbf{C}$ and its subgroups, with nearly everyone being in haplogroups $\mathbf{J 1} \mathbf{c} \mathbf{2} \mathbf{c} \mathbf{1}$ and $\mathbf{J 1} \mathbf{c 2} \mathbf{c 2}$. The possible population size of haplogroup $\mathbf{J 1} \mathbf{c 2} \mathbf{c} \mathbf{3}$ is estimated in this article to be at most just a few hundreds (see Table 1 which illustrates this point).

Table 1. Haplogroup J details

\begin{tabular}{|c|c|}
\hline Haplogroup & Estimated population size \\
\hline J & 100 million \\
\hline$\vdash \mathrm{J1}$ & 75 million \\
\hline$\vdash J 1 c$ & 57 million \\
\hline$-J 1 c_{2}$ & 17 million \\
\hline$\vdash J 1 c 2 c$ & 3 million \\
\hline$J 1 \mathrm{c} 2 \mathrm{C}$ & 0.5 million (unassigned) \\
\hline $\mathrm{J} 1 \mathrm{c} 2 \mathrm{c} 1$ & 1.25 million \\
\hline $\mathrm{J} 1 \mathrm{c} 2 \mathrm{c2}$ & 1.25 million \\
\hline $\mathrm{J} 1 \mathrm{c} 2 \mathrm{c} 3$ & $300 ?$ \\
\hline
\end{tabular}

Note: The 'Haplogroup' column uses the haplogroup labels as given on the latest phylogenetic tree. The 'Estimated population size' gives the figures obtained by using a pro rata calculation starting with haplogroup $\mathbf{J}$ being taken as having a size of 100 million people and having about 1500 sequences on the GenBank database. There are about 1150 sequences for haplogroup J1, about 850 for haplogroup J1c, etc. For the larger haplogroups the population estimates are rounded to the nearest million people. 
The search for mitochondrial descendants of King Richard III

John Ashdown-Hill ${ }^{22}$ was able to identify one lineage of descent from Richard III's elder sister, Anne of York. This line led to Joy lbsen and her son Michael, who at the time were both living in Canada. The team of researchers at the University of Leicester was able to construct a different lineage and this led to Wendy Duldig who lives in New Zealand. ${ }^{23}$ But it has not been generally appreciated that $\mathbf{J 1} \mathbf{c 2} \mathbf{c 3}$ has not been identified in any people living in Europe. However, in this study we are able to describe a further seven lineages, all from the USA, that match the mtDNA haplogroup of Richard III, and to discuss the features of Richard III's mtDNA that make it so very special.

\section{Methods}

\section{Haplogroup J1c2c3 sequences in the public domain database GenBank ${ }^{24}$}

The report from the University of Leicester indicates that complete mtDNA sequencing of samples taken from the skeletal remains of King Richard III was attempted and proved successful. ${ }^{25}$ The team also sequenced the mtDNA from both Michael Ibsen and Wendy Duldig. These complete mtDNA sequences do have the mutations expected for haplogroup J1 $\mathbf{c 2} \mathbf{c} 3$ and therefore indicate that the three persons are likely to be closely related. The sequences themselves have been submitted to the GenBank database and can be found at:

- https://www.ncbi.nlm.nih.gov/nuccore/KM676292 - for King Richard III

- https://www.ncbi.nlm.nih.gov/nuccore/KM676293 - for Michael Ibsen

- https://www.ncbi.nlm.nih.gov/nuccore/KM676294 - for Wendy Duldig

\section{Haplogroup J1c2c3 sequences in commercial databases}

There are three main commercial companies that test samples on a direct-to-customer basis, but the free access to their database results is restricted. However, once customers have their own results on a database, it is possible for them to access some of the details of their matches and make contact with these people via a messaging service or email.

(1) FamilytreeDNA of Houston, Texas does complete mtDNA sequencing using a Next-Generation-Sequencing method and says it has a database of about 250,000 sets of results. ${ }^{26}$ The company does allow its customers to get the details of close mtDNA matches by the use of a genetic distance system.

(2) 23andMe of Mountain View, California uses a chip-based system which tests for about $2000 \mathrm{mtDNA}$ SNPs and this is sufficient to identify haplogroup J1c2c3. Unfortunately, the company does not allow for mtDNA haplogroup matches to be found from its extensive database, and matching possibilities are restricted to the disclosure of the mtDNA haplogroup by each of a person's DNA relatives. A further problem with the results from this company is that only haplogroup $\mathbf{J 1} \mathbf{c} \mathbf{2} \mathbf{c}$ is reported and it is necessary to look specifically at the Raw Data File to see if the result for SNP i4000775 is a G as is needed for haplogroup J1c2c3. It is to be hoped that 23andMe will update its mitochondrial haplogroup labelling in due course to include J1c2c3.

(3) National Geographic Store of Margate, Florida as part of its Genographic Project ${ }^{27}$ offers a similar chip-based system and does properly identify haplogroup J1c2 $\mathbf{c 3}$. Moreover, this company does let a customer match on their mitochondrial haplogroup label but it would appear there is just a single set of results in this company's database from haplogroup J1c2c3.

Recently several other commercial companies have started to perform mtDNA sequencing but so far as is known nobody has been identified as being in haplogroup J1c2c3.

\section{Searching for other members of haplogroup J1c2c3}

The search for further members of haplogroup $\mathbf{J 1} \mathbf{1} \mathbf{2} \mathbf{c} 3$ has been conducted by one of the authors (David Brinkman) who found that he was in this rare haplogroup after doing his own direct-to-customer testing. The announcement that King Richard III was also in J1c2c3 has made the subsequent search all the more interesting. Looking for possible mtDNA matches has involved the construction of a detailed ancestral tree (see Lineage DNB below), contacting matches in the commercial databases, joining the Richard III Society and giving interviews to the press. The methods are very similar to those described in a recent paper ${ }^{28}$ which gives details of a search for people in haplogroup $\mathbf{H 7}$.

\section{Results}

The search for members of haplogroup $\mathbf{J 1} \mathbf{c} \mathbf{2} \mathbf{c} \mathbf{3}$ has led to the discovery of seven separate lineages of the ancestors of the people who have been identified as belonging to this rare haplogroup. The lineages show the maternal line of descent (as mtDNA is maternally inherited), but in many instances it is the husbands for whom there is much more documentary evidence. Unfortunately, except in the last lineage, the link back to the original immigrants into the Americas is unknown. Also, none of the lineages can be connected to Plantagenet families either in the USA or in England. 
The lineages are described here and illustrated in Appendix A.

(1) Lineage DNB: This lineage is associated with the State of North Carolina, and goes back to Joel Hollowell (1727-74) and his wife Miriam Perry (1723-70). The couple lived in Perquimans County, NC, but Miriam is thought to have been born in Nansemond County, VA, and this is much closer to the early colonies established at Yorktown and Elizabeth City.

(2) Lineage DB: This lineage is associated with the State of Virginia, and goes back to Daniel Carter (1738-94) and his wife Rachel (174595). Nothing is known about this couple, but their daughter Mary Carter (1766-1847) married an American Revolutionary War veteran, David Pagan (1745-1815) and subsequently claimed a pension. It also appears that Mary and David Pagan owned land on Grimes Creek, near Oyler's Chapel, south-east of Roanoke, VA.

(3) Lineage EG: This lineage is associated with the State of Missouri, and goes back to Samuel Cobb (1794-1881) and his wife Lenora Taylor (1800-83). It is thought that Lenora came from Virginia and Samuel perhaps from Kentucky. A memorial stone for Lenora can be seen at the New Providence Cemetery, Montgomery City, MO and shown on http://www.findagrave.com (\#28698419), where her name is given as Senora Taylor Cobb.

(4) Lineage KS: This lineage is associated with the State of New York, and goes back to Timothy R. Tubbs (1804-) and his wife (name unknown). Timothy R. Tubbs and his daughter Nancy Jane Tubbs (1837-1917) can be found on the census for Keating, Potter County, PA in 1850 and 1860. Keating is a small settlement very close to the New York State border.

(5) Lineage KW: This lineage is associated with the State of New York, or possibly Maryland, and goes back to Cornelius Westbrook Totten (1817-93) and his wife Dorcas Lewis (1829-1905). Dorcas was probably born in New York State, although on one census Maryland is mentioned. Cornelius and Dorcas Totten can be found on the 1860, 1870 and 1880 censuses for Nescopeck, PA. A memorial stone for Dorcas can be seen at the Old Mount Zion Cemetery, Hobbie, PA and is shown on http://www.findagrave.com (\#21848944).

(6) Lineage LD: This lineage is associated with the State of Connecticut, and goes back to Ira Bigelow (1763-1823) and his wife Rachel Allen (1765-1812). This couple married in Westchester, CT on 10 June 1784. Ira Bigelow is known to have served in the Connecticut Militia in the American Revolutionary War. The couple's daughter Aurelia Bigelow married Solomon Sherwood and lived in North Royalton, $\mathrm{OH}$ for many years. A memorial stone for Aurelia can be seen at the North Royalton Cemetery, $\mathrm{OH}$ and is shown on http:// www.findagrave.com (\#11236480).

(7) Lineage GU: This lineage, the latest to be discovered and still being researched, goes back from New York to Australia and to southwest England, where Daniel Clapp married Sarah Moore on 5 April 1818 in the parish of Churchstanton (then in Devon but now in Somerset).

The above lineages must be viewed with discretion as in most cases we have identified only a single descendant in haplogroup J1c2c3. However, with lineage DNB there is more confidence as there are several descendants who have had DNA tests showing that they belong to haplogroup J1c2c3.

\section{Discussion}

John Ashdown-Hill ${ }^{29}$ and the researchers at the University of Leicester ${ }^{30}$ have each identified maternally related descendants of King Richard III by using the orthodox genealogical approach of constructing family trees in a top-down, or descendant-driven, manner; and in both instances they were fortunate to be successful. In contrast, in our study we have used a bottom-up, or ancestor-driven, method. Direct-to-customer mtDNA testing has shown that several people share the same uncommon mitochondrial haplogroup as King Richard III and we have tried to construct maternal ancestral lineages for these people to see if we can reach back to England and ultimately connect to the family of King Richard III itself. But, unfortunately, none of the first six lineages that we describe here reaches back far enough and in this respect our search has proved so far to be unsuccessful. However, genealogy is not just about the construction of family trees, as it also enables us to look at our ancestors and understand the simple facts of who they were, where they lived, and what they did, and learn about the world in their time. So looking first at the lineages DNB, DB and EG, we have found that the lineages go back in the southern states of North Carolina, Virginia and Missouri; and it would seem reasonable to suggest they might all have a common origin in a family arriving in Yorktown, Elizabeth City or some other southern city, in the late seventeenth or early eighteenth centuries. The period just after the English Civil War (1642-1651) was a period of great turmoil in England and many people left the country. They did this for reasons of religious intolerance and other forms of persecution, lack of employment, and in many cases more simply the perennial threat of starvation. The Americas were seen not just as a place of bounty, but also as a place free of the problems of England. However, it is not possible to say definitely that these lineages show immigration into the States of people from England. But, as all the names appear to be English and the areas in which they settled were predominantly English, it would appear very likely that these southern J1c2c3 lineages do derive from England.

The three lineages KS, KW and LD are distinctly different as they have links to places in the northern states of New York and Connecticut; and they appear to reflect immigration into the States perhaps a century after the southern lineages. These northern lineages might also have a 
common root, but it is equally possible that they reflect the arrival of different J1c2c3 families, and not necessarily all from England. However, the families do appear to have a wish to preserve the use of English biblical names, for example both Dorcas and Rachel were common in England. The emigration of people to the States in the late eighteenth and early nineteenth centuries was mainly driven by the enclosure of common land and the early influence of the Industrial Revolution which combined to force many into the cities; from which one route of escape was to emigrate to the USA.

The final lineage, GU, is somewhat different as we do find a link back to England, and an immigration into the USA in the twentieth century. Unfortunately, however, the lineage cannot be shown to connect to any known descendants of the family of King Richard III.

As well as researching the lineages of persons who have been found to be in haplogroup $\mathbf{J 1} \mathbf{1} \mathbf{2} \mathbf{c} \mathbf{3}$, this article provides the opportunity to examine the evidence that makes $\mathbf{J 1 C 2} \mathbf{c 3}$ so special and such a good example of how mitochondrial results can be used to further genealogical researches. It is therefore appropriate to discuss the genetic basis of haplogroup $\mathbf{J}$ and its subgroups in some detail.

It is interesting to note at this point that the mutation A12397G in itself is not a particularly uncommon mutation as it occurs in about 1 in 200 of the mtDNA sequences present on the GenBank database. The mutation is to be found sporadically in sequences of many different haplogroups, but it is only in sequences from both haplogroups $\mathbf{X 2 \mathbf { 2 }}$ (Native American) and $\mathbf{X 2 \mathbf { j }}$ (Egyptian) that it occurs in every sequence and therefore acts as a defining mutation for the two groups. The finding of the sequences in the closely related groups $\mathbf{X} \mathbf{2} \mathbf{a}$ and $\mathbf{X} \mathbf{2} \mathbf{j}$ is presumably just a coincidence and does not indicate a true link between Egypt and North America. 'A12397G' indicates that the 12397th nucleotide base of the mtDNA is changed (relative to the CRS) from an Adenine to a Glycine. In this instance the mutation does have a demonstrable effect as it causes a change in the protein MT-ND5 (NADH dehydrogenase 5), of the 21st amino acid, from the more usually occurring Threonine to the slightly smaller in size amino acid Alanine (a change described as T21A). A change of an amino acid with these characteristics, i.e. caused by a mutation that is common enough to define a haplogroup, and to a smaller amino acid near the end of a protein, is usually considered to be harmless, and therefore the mutation causing the change can be described as a simple polymorphism. Overall, it would appear that the appearance of the mutation A12397G in haplogroup J1c2 c3 is to be accepted as a harmless and random occurrence. ${ }^{31}$

It is also relevant at this point to look at the details for the mutation G8994A in a similar way. This mutation is found in the mtDNA sequence of the known descendant, Wendy Duldig, and has appeared as a sporadic mutation in her lineage sometime after the divergence of her line from that of Michael Ibsen in the sixteenth century. G8994A is a much more commonly seen mutation than A12397G as it is found in about 1 in 50 of the sequences on the GenBank database and is a defining mutation in haplogroups $\mathbf{W}$, Lok, and others. This mutation comes in the gene for the protein MT-ATP6, but does not cause any change to the protein. So, as with the mutation A12397G, this later mutation G8994A is also considered a simple polymorphism.

The mitochondrial sequences for the majority of the people identified in this study do exactly match the sequences obtained from King Richard III and Michael Ibsen (GenBank sequences KM676292-3). However, two sequences may have additional mutations in the hypervariable region, which can be expected to happen and can be considered to be insignificant. But more importantly, the sequence from subject 'GU' (GenBank sequence KY980656) does show the additional mutation C1494T - a highly significant mutation. It is hoped that the presence, or absence, of this mutation will be confirmed in the near future.

\section{Conclusion}

The above discussion about haplogroup J1 $\mathbf{c 2} \mathbf{c 3}$ would seem to leave two questions to be answered: (1) How many people can be expected to be in haplogroup J1c2 $\mathbf{c 3}$ ? And (2) Does being in haplogroup J1c2c3 indicate a close link to the family of King Richard III? Putting these questions another way, is there evidence to support the hypothesis that haplogroup J1 $\mathbf{c 2} \mathbf{c} \mathbf{3}$ is the haplogroup of the immediate family of King Richard III, and that the few people identified as being in this haplogroup are true descendants of close female family members? Or does the evidence refute this?

In this study we have identified seven lineages for people who have found they are in haplogroup J1 c2 $\mathbf{c 3}$, and the construction of their family trees allows us to suggest that we have identified approximately one hundred descendants who can be expected to have this mtDNA haplogroup; albeit at present very few of the descendants have had their haplogrouping confirmed. It is certain that further lineages will continue to appear, but it would seem unlikely that there are a great number of new lineages to be found. So the number of people in haplogroup J1c2c3 would seem to be very small; perhaps just a few hundred.

Everyone who has been identified as being in haplogroup J1 $\mathbf{c} \mathbf{2} \mathbf{3}$ would appear to have a stronger link to England than to any other country. We therefore suggest that all the people we have identified can claim to be descendants of the female members of the family of King Richard 
III. While there is no proof that there was just the single immigration of only one person from haplogroup J1c2c3 from Europe into England (but nobody in Europe has been shown to be in this subgroup), for the present the authors suggest the lineages described may be part of the family of King Richard III.

Our study is very much work in progress and we continue to be contacted by new people as they find that their mtDNA haplogroup is J1c2c3. For most of the new contacts it can be readily shown that they are descendants of people who are already on one of the lineages described above, whilst others appear to have a link to a known city or area and can be presumed to be descendants, but in these cases there is an absence of documentary proof and further work is required. We would very much appreciate being contacted by anyone who finds they are in haplogroup J1 $\mathbf{c 2 c 3}$, and also anyone who can provide additional details for our family trees. Our real hope for the future is to find descendants of King Richard III's family for whom lines of descent can be found that are as good as those for Michael lbsen and Wendy Duldig.

\section{Citation information}

Cite this article as: Logan, lan S. and Brinkman, David N. (2017) King Richard III and his mitochondrial DNA haplogroup J1c2c3. Journal of Genealogy and Family History. 1(1) http://dx.doi.org/10.24240/23992964.2017.030102

\section{References}

1. Shakespeare, William. (1978) The Alexander text of William Shakespeare. The complete works. London: Collins.

2. Ashdown-Hill, John. (2010, revised 2013) The last days of Richard III. Stroud: The History Press.

3. Skidmore, Chris. (2013) Bosworth. London: Weidenfeld \& Nicolson.

4. Ashdown-Hill, John. (2010, revised 2013) The last days of Richard III. Stroud: The History Press.

5. Langley, Philippa and Jones, Michael. (2013) The search for Richard III. The king's grave. London: John Murray.

6. King, T. E., Fortes, G. G., Balaresque, P., Thomas, M. G., Balding, D., Maisano Delser, P. Neumann, R., Parson, W., Knapp, M., Walsh, S., Tonasso, L., Holt, J., Kayser, M. Appleby, J., Forster, P., Ekserdjian, D., Hofreiter, M. and Schürer, K. (2014) Identification of the remains of King Richard III. Nature Communications. 5. p. 5631

7. Bettinger, Blaine T. and Wayne, Debbie Parker. (2016) Genetic genealogy in practice. Arlington, VA: National Genealogical Society.

8. Bettinger, Blaine T. (2016) The family tree guide to DNA testing and genetic genealogy. Cincinnati, OH: Family Tree Books.

9. Anderson, S., Bankier, A. T., Barrell, B. G., de Bruijn, M. H., Coulson, A. R., Drouin, J., Eperon, I. C., Nierlich, D. P., Roe, B. A., Sanger, F., Schreier, P. H., Smith, A. J., Staden, R. and Young, I. G. (1981) Sequence and organization of the human mitochondrial genome. Nature 290(5806). pp. 457-65.

10. Andrews, R. M., Kubacka, I., Chinnery, P. F., Lightowlers, R. N., Turnbull, D. M., and Howell, N. (1999) Reanalysis and revision of the Cambridge reference sequence for human mitochondrial DNA. Nature Genetics. 23(2). p. 147.

11. Bandelt, H. J., Kloss-Brandstätter, A., Richards, M. B., Yao, Y. G. and Logan, I. (2014) The case for the continuing use of the revised Cambridge Reference Sequence (rCRS) and the standardization of notation in human mitochondrial DNA studies. Journal of Human Genetics. 59(2). pp. 66-77.

12. Huang, Taosheng. (2011) Next generation sequencing to characterize mitochondrial genomic DNA heteroplasmy. Current Protocols in Human Genetics. Chapter 19, Unit 19.8. https://www.ncbi.nlm.nih.gov/pmc/articles/PMC4687495/

13. Parsons, Thomas J. (2006) Mitochondrial DNA genome sequencing and SNP assay development for increased power of discrimination. National Criminal Justice Reference Service. https://www.ncjrs.gov/pdffiles1/nij/grants/213502.pdf

14. Cann, R. L., Stoneking, M. and Wilson A. C. (1987) Mitochondrial DNA and human evolution. Nature. 325. pp. 31-6.

15. Torroni, A., Schurr, T. G., Cabell, M. F., Brown, M. D., Neel, J. V., Larsen, M., Smith, D. G., Vullo, C. M. and Wallace, D. C. (1993) Asian affinities and continental radiation of the four founding Native American mtDNAs. American Journal of Human Genetics. 53(3). pp. 563-90.

16. Torroni, A., Lott, M. T., Cabell, M. F., Chen, Y. S., Lavergne, L. and Wallace, D. C. (1994) mtDNA and the origin of Caucasians: identification of ancient Caucasian-specific haplogroups, one of which is prone to a recurrent somatic duplication in the D-loop region. American Journal of Human Genetics. 55(4). pp. 760-6.
17. Richards, M., Côrte-Real, H., Forster, P., Macaulay, V., Wilkinson-Herbots, H., Demaine A., Papiha, S., Hedges, R., Bandelt, H.J. and Sykes, B. (1996) Paleolithic and neolithic lineages in the European mitochondrial gene pool. American Journal of Human genetics. 59(1). pp. 185-203.

18. Torroni, A., Bandelt, H. J., D'Urbano, L., Lahermo, P., Moral, P., Sellitto, D., Rengo, C., Forster, P., Savontaus, M. L., Bonné-Tamir, B. and Scozzari, R. (1998) mtDNA Analysis reveals a major Late Paleolithic population expansion from southwestern to northeastern Europe. (1998) American Journal of Human Genetics. 6. pp. 1137-52.

19. Sykes, Bryan. (2001) The seven daughters of Eve. London: Bantam Press.

20. Pala, M., Olivieri, A., Achilli, A., Accetturo, M., Metspalu, E., Reidla, M., Tamm, E., Karmin, M., Reisberg, T., Hooshiar Kashani, B., Perego, U. A., Carossa, V., Gandini, F., Pereira, J. B., Soares, P., Angerhofer, N., Rychkov, S., Al-Zahery, N., Carelli, V., Sanati, M. H., Houshmand, M., Hatina, J., Macaulay, V., Pereira, L., Woodward, S. R., Davies, W., Gamble, C., Baird, D., Semino, O., Villems, R., Torroni, A. and Richards, M. B. (2012) Mitochondrial DNA signals of late glacial recolonization of Europe from near eastern refugia. American Journal of Human Genetics. 90(5). pp. 915-24.

21. van Oven M. and Kayser M. (2009) Updated comprehensive phylogenetic tree of global human mitochondrial DNA variation. Human Mutation. 30(2). pp. E386-94. www.phylotree.com

22. Ashdown-Hill, John. (2010, revised 2013) The last days of Richard III. Stroud: The History Press.

23. King, T. E., Fortes, G. G., Balaresque, P., Thomas, M. G., Balding, D., Maisano Delser, P., Neumann, R., Parson, W., Knapp, M., Walsh, S., Tonasso, L., Holt, J., Kayser, M., Appleby, J., Forster, P., Ekserdjian, D., Hofreiter, M. and Schürer, K. (2014) Identification of the remains of King Richard III. Nature Communications. 5. p. 5631.

24. Benson, D. A., Karsch-Mizrachi, I., Lipman, D. J., Ostell, J., and Wheeler D. L. (2005) GenBank. Nucleic Acids Research. 33(Database Issue). pp. D34-38.

25. King, T. E., Fortes, G. G., Balaresque, P., Thomas, M. G., Balding, D., Maisano Delser, P., Neumann, R., Parson, W., Knapp, M., Walsh, S., Tonasso, L., Holt, J., Kayser, M., Appleby, J., Forster, P., Ekserdjian, D., Hofreiter, M. and Schürer, K. (2014) Identification of the remains of King Richard III. Nature Communications. 5. p. 5631.

26. FamilytreeDNA. https://www.familytreedna.com/why-ftdna.aspx: accessed April 2017.

27. Wells, Spencer. (2006) Deep ancestry: inside the Genographic Project. Washington D. C: National Geographic.

28. Yacobi, Doron and Bedford, Felice L. (2016) Evidence of early gene flow between Ashkenazi Jews and non-Jewish Europeans in mitochondrial DNA haplogroup H7. Journal of Genetic Genealogy. 8 (1). http://www.jogg.info

29. Ashdown-Hill, John. (2010, revised 2013) The last days of Richard III. Stroud: The History Press.

30. King, T. E., Fortes, G. G., Balaresque, P., Thomas, M. G., Balding, D., Maisano Delser, P., Neumann, R., Parson, W., Knapp, M., Walsh, S., Tonasso, L., Holt, J., Kayser, M., Appleby, J., Forster, P., Ekserdjian, D., Hofreiter, M. and Schürer, K. (2014) Identification of the remains of King Richard III. Nature Communications. 5. p. 5631

31. Martín-Navarro, A., Gaudioso-Simón, A., Álvarez-Jarreta, J., Montoya, J., Mayordomo, E. and Ruiz-Pesini, E. (2017) Machine learning classifier for identification of damaging missense mutations exclusive to human mitochondrial DNA-encoded polypeptides. BMC Bioinformatics. 18(1). p. 158. 
Appendix A: Partial ancestral trees of the seven lineages confirmed having J1c2c3 descendants

Each tree shows three to five generations of a different lineage. The names of the subjects are given in their commonest form. Dates expressed in full are taken from the available records, but dates expressed only as a year should be considered as unconfirmed and a range of $+/$ - two years may be applicable. The mention of 'see: www.findagrave.com' indicates that a reference page can be found on the website, but not necessarily with a photograph of a memorial stone. The mention of a year followed by a place of residence indicates a census entry. The female subjects in the trees are all marked as being in haplogroup $\mathbf{J 1} \mathbf{c 2} \mathbf{c 3}$, but it is only in Lineage DNB that there is enough evidence to suggest that this is correct.

\section{a. Lineage DNB}

\begin{tabular}{|c|c|c|}
\hline \begin{tabular}{l|l} 
Joel HOLLOWELL & Mi \\
b. 1727 Perquimans, NC & b. \\
d. Jul 1774 NC & m. \\
Himself & d. \\
\end{tabular} & \multicolumn{2}{|c|}{$\begin{array}{l}\text { Miriam PERRY } \\
\text { b. } 1723 \text { Nansemond Co., VA } \\
\text { m. about } 1745 \text { Perquimans, NC } \\
\text { d. } 1770 \text { NC } \\
\text { 'J1c2c3' }\end{array}$} \\
\hline $\begin{array}{l}\text { Susannah HOLLOWELL } \\
\text { b. } 1750 \text { Perquimans, NC } \\
\text { d. } 1828 \text { Pasquotank, NC } \\
\text { 'J1c2c3' } \\
\text { Daughter }\end{array}$ & \multicolumn{2}{|c|}{\begin{tabular}{|l|} 
Ebenezer SAW YER \\
b. 1735 Pasquotank, NC \\
m. 1760 Pasquotank, NC \\
d. 12 Dec 1802 Pasquotank, NC
\end{tabular}} \\
\hline $\begin{array}{l}\text { Penelope 'Penny' SAWYER } \\
\text { b. } 1767 \text { Pasquotank, NC } \\
\text { d. } 1855 \text { Camden, NC } \\
\text { 'J1c2c3' } \\
\text { Grand Daughter }\end{array}$ & \multicolumn{2}{|c|}{$\begin{array}{l}\text { Edmond SAWYER } \\
\text { b. } 21 \text { Sep } 1761 \text { Pasquotank, NC } \\
\text { m. - } \\
\text { d. before } 1840 \text { Camden, NC }\end{array}$} \\
\hline \multicolumn{2}{|c|}{$\begin{array}{l}\text { Mary 'Polly' SAWYER } \\
\text { b. } 1790 \text { Camden, NC } \\
\text { d. } 8 \text { Jul } 1821 \text { Pasquotank Co., NC } \\
\text { 'J1c2c3' } \\
\text { Great Grand Daughter }\end{array}$} & $\begin{array}{l}\text { Lemuel JENNINGS } \\
\text { b. } 22 \text { Nov } 1782 \text { Pasquotank, NC } \\
\text { m. } 9 \text { Jun } 1807 \text { Pasquotank, NC } \\
\text { d. } 29 \text { Jan } 1832\end{array}$ \\
\hline \multirow{2}{*}{\begin{tabular}{|l|} 
Elizabeth JENNINGS \\
b. 28 Jan 1812 NC \\
d. 17 May 1859 \\
bur. Elizabeth City, NC \\
'J1c2c3' \\
1850 Pasquotank \\
2nd Great Grand Daughter
\end{tabular}} & \multicolumn{2}{|c|}{$\begin{array}{l}\text { Philip PRITCHARD } \\
\text { b. } 1808 \text { Pasquotank Co., NC } \\
\text { m. } 11 \text { Feb } 1830 \text { Pasquotank,Carolina } \\
\text { d. } 29 \text { Dec } 1848 \\
\text { bur. Elizabeth City, NC }\end{array}$} \\
\hline & & \\
\hline
\end{tabular}




\section{b. Lineage DB}

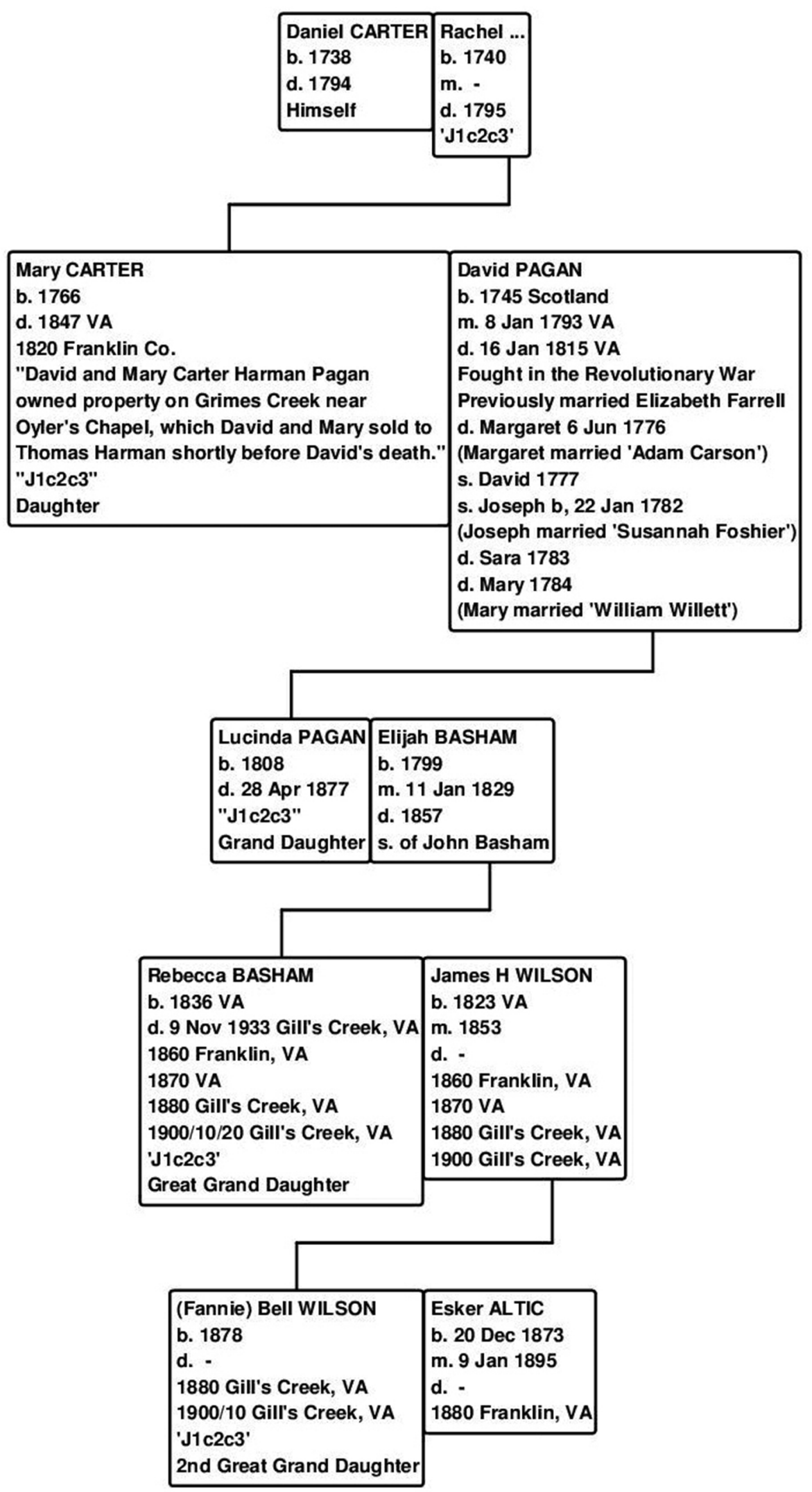




\section{c. Lineage $\mathbf{E G}$}

Samuel COBB
b. $1794 \mathrm{KY}$
d. 30 Aug 1881 Montgomery Co., MO
Family moved 1823 to 'Cobbtown, MO'
1840 Danville, MO
1850 Montgomery Co., MO
1860 Danville, MO
1880 Montgomery, MO
Himself

Lenora TAYLOR

b. 1800 VA

m. 1838

d. 18 Mar 1883 Montgomery Co., MO

bur. New Providence Cem., MO

see: www.findagrave.com

'J1c2c3'

1850 Montgomery Co., MO 'Lenoria' 'age 49' 1860 Danville, MO 'Lena' 'age 61'

1880 Montgomery, MO 'Sennora' 'age 66'

Virginia Shelton COBB
b. 12 Jul 1842 MO
d. 14 Jun 1927 Shamrock, MO
bur. - Liberty Cem., MO
see: www.findagrave.com
1850 Montgomery Co., MO
1860 Danville, MO
1870 MO (+ Sarah C Cobb age 15)
1880 Nine Mile Prairie, MO
$1900 / 20$ Shamrock, MO
'J1c2c3'
Daughter

John Patton SIGLER

b. 18 Apr $1843 \mathrm{OH}$

m. 18 Oct 1864 Montgomery Co., MO

d. 19 Jan 1900 Shamrock, MO

bur. - Liberty Cem., MO

see: www.findagrave.com

1870 MO

1880 Nine Mile Prairie, MO

\begin{tabular}{|l|}
\hline Louvantia SIGLER \\
b. 1865 MO \\
d. 1896 Shamrock, MO \\
bur. - Liberty Cem., MO \\
see: www.findagrave.com \\
1870 MO \\
1880 Nine Mile Prairie, MO \\
'J1c2c3' \\
Grand Daughter
\end{tabular}

Henry Ashley OVERBAUGH

b. $1859 \mathrm{NY}$

m. 27 Oct 1892

d. -

1860/65 Catskill, NY

$1870 \mathrm{MO}$

1880 Martinsburg, MO

1900 Loutre, MO

1940 Rocky Ford, CO

Ethel Catherine OVERBAUGH Glenn Thurston MALTBY

b. 24 Jul 1893

d. 9 Dec 1930 CO

bur. - Crown Hill Cem., CO

b. 20 Jul 1889 Foosland, IL

m. 11 Aug 1914 Rocky Ford, CO

see: www.findagrave.com d. 17 May 1982 CA

bur. - Crown Hill Cem., CO

1900 Loutre, MO

see: www.findagrave.com

1920 Brighton, CO

1900 Brown, IL

'J1c2c3'

Great Grand Daughter

1920 Brighton, CO

1930 Eastlake, CO

1940 Bailey, TX 


\section{d. Lineage $\mathrm{KS}$}

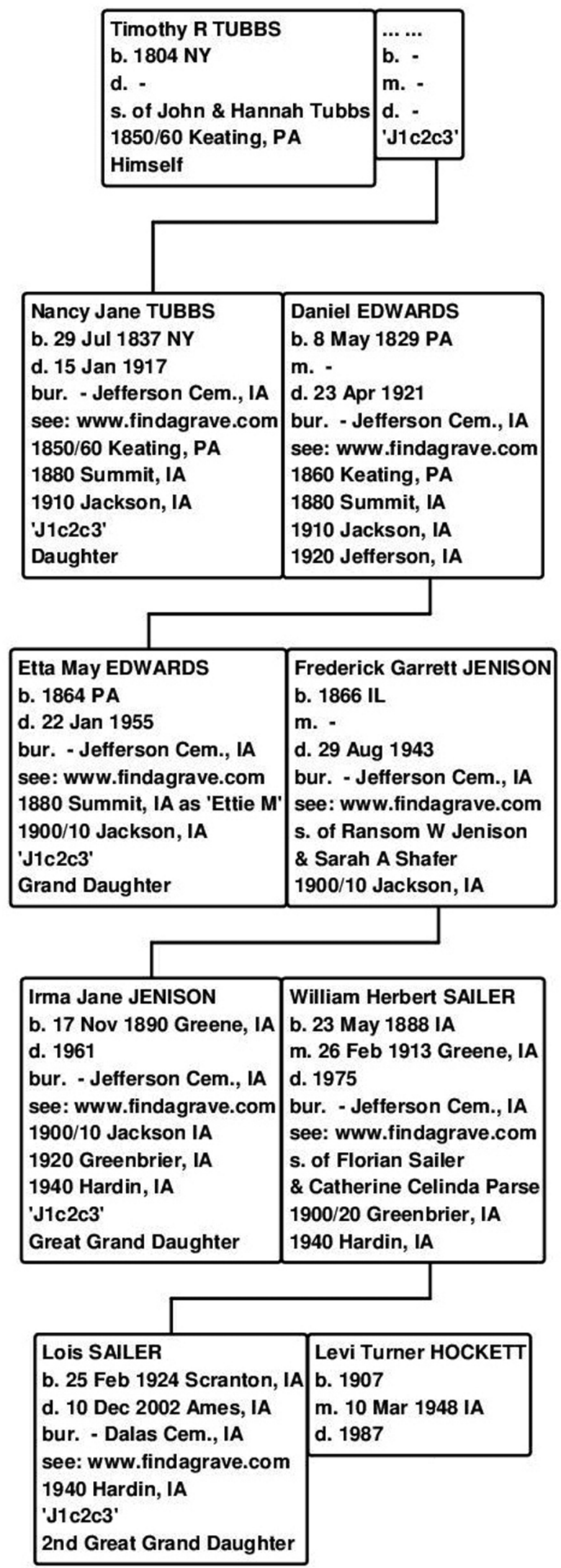




\section{e. Lineage $\mathrm{KW}$}

Cornelius Westbrook TOTTEN

b. $1817 \mathrm{NY}$

d. 28 Feb 1893

bur. - Old Mount Zion Cem., PA

see: www.findagrave.com

1860/70/80 Nescopeck, PA

Himself
Dorcas LEWIS

b. 15 Oct $1829 \mathrm{NY} / \mathrm{MD}$

m. -

d. 29 Dec 1905 Luzerne Co., PA

bur. - Old Mount Zion Cem., PA

see: www.findagrave.com

'J1c2c3'

1860/70/80 Nescopeck, PA

1900 Roanoke, VA
Frances A TOTTEN

b. 3 Apr 1853 Wapwallopen, PA

d. 11 Aug 1914 Nanticoke, PA

bur. - Powder Glen Cem., PA

see: www.findagrave.com

'J1c2c3'

1860/70 Nescopeck, PA

1880/1900 Hollenback, PA

Daughter

\section{Hiram MOYER}

b. 16 Nov 1850 Luzerne Co., PA

m. -

d. 8 Jan 1908 Luzerne Co., PA

bur. - Powder Glen Cem., PA

see: www.findagrave.com

$1880 / 1900$ Hollenback, PA \& mother

Mary Dorcas MOYER

b. 7 Jul 1876 Luzerne Co., PA

d. 18 Jan 1934 Danville, PA

EImer Ellsworth GROVER

bur. - Old River Church Cem., PA

b. 11 Jul 1860 Luzerne Co., PA m. -

see: www.findagrave.com

'J1c2c3'

1880/1900 Hollenback, PA

1910/20/30 Conyngham, PA

Grand Daughter

d. 28 Oct 1949 Wapwallopen, PA bur. - Old River Church Cem., PA see: www.findagrave.com son of Joshua \& Ellen Grover 1870 Pennsylvania 1910/20/30 Conyngham, PA

Virginia Frances GROVER b. 9 Oct 1914 Wapwallopen, PA d. 6 Feb 2001 Berwick, PA John Miller GILBERT bur. - Old River Church Cem., PA see: www.findagrave.com 'J1 c2c3'

1920/30 Conyngham, PA Great Grand Daughter

John Miles GILBERT

b. 22 Nov 1940 Hazleton, PA

d. 29 Dec 2011 Ormond Beach, FL bur. - Old River Church Cem., PA see: www.findagrave.com 'J1c2c3'

2nd Great Grand Son 


\section{f. Lineage LD}

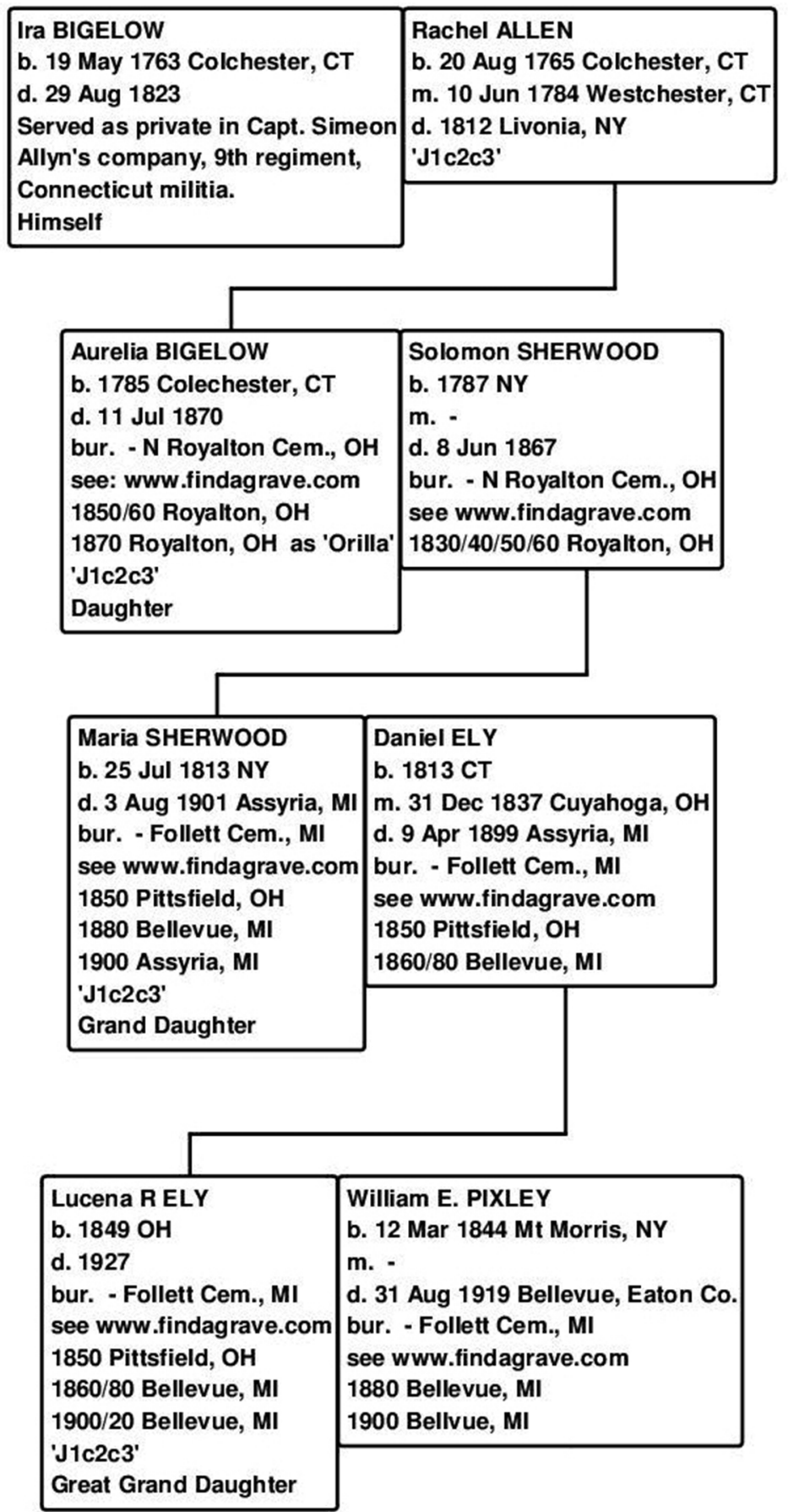




\section{g. Lineage GU}

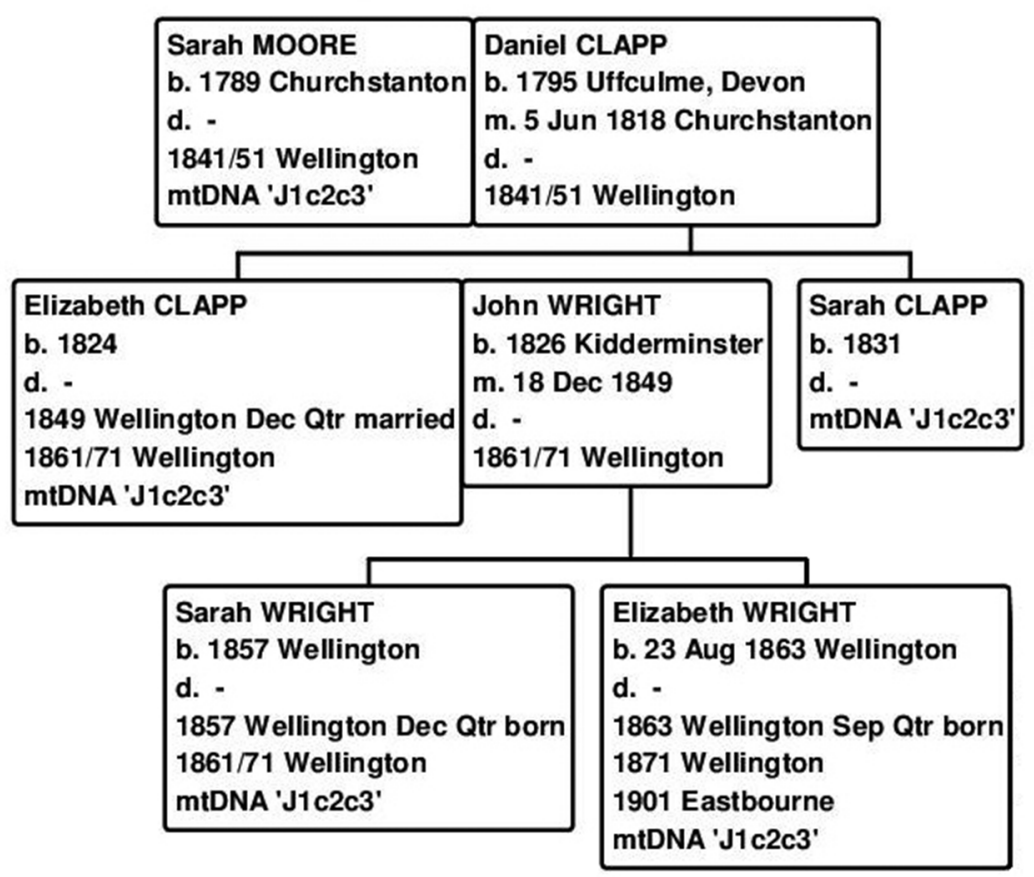

\section{ABOUT THE AUTHORS}

lan Logan is a retired medical practitioner living in Exmouth, Devon, UK. He has been involved with genealogy for over twenty years and is a committee member and Record Keeper for the Brooking Society. He has authored and co-authored several papers about different aspects of mitochondrial DNA and has a special interest in Leber Hereditary Optic Neuropathy. He maintains a personal website with nearly 1000 pages dealing with the mtDNA sequences available in the public domain, sorted by their haplogroups.

Email: ianlogan22@btinternet.com

David Brinkman is a software engineer living in Columbia, South Carolina, USA and was extremely pleased and fascinated to find that his mtDNA sequence matched that of King Richard III. He is a keen amateur archaeologist looking at his local region and has recently received the 2017 Distinguished Archaeologist of the Year Award from the Archaeological Society of South Carolina. For the last four years he has been co-ordinating a search in America for other mitochondrially related descendants of the family of King Richard III.

Email: dobrink@gmail.com 